\title{
Pengembangan Media Pembelajaran Berbasis Video dalam Meningkatkan Pemahaman Qur'an dan Makna (Qurma) pada Surat Al-Humazah di MI Narrative Quran Lamongan
}

\author{
Siti Munawaroh ${ }^{1}$, Abdulloh Hamid ${ }^{2}$, Rudy Al Hana ${ }^{3}$, Mohammad Salehudin ${ }^{4}$ \\ ${ }^{1,2,3}$ Pascasarjana UIN Sunan Ampel Surabaya, ${ }^{4}$ Institut Agama Islam Negeri Samarinda \\ 11ceteem59@gmail.com'2doelhamid@uinsby.ac.id ${ }^{3}$ rudy.alhana@uinsby.ac.id, \\ ${ }^{4}$ salehudin@iain-samarinda.ac.id
}

\begin{abstract}
The Qur'an as a guide to life must be understood its meaning. Often found, the study of short Surats material revolves around reading verses, memorizing, and knowing the meaning only. In MI Narrative Quran, there are subjects of Qur'an and Meaning (Quran dan Makna/Qurma). In addition to being able to read and know its meaning, students are also required to be able to understand the content of the Qur'an. The research aims to create a video-based learning media product in understanding Qurma Surat Al-Humazah. This research using Research and Development (R\&D) method by applying six steps, namely: potential and problems, data collection, product design, design validation, design revision, and product trial. The feasibility of learning media in the form of video has been assessed using questionnaires by media experts, material experts, and grade 3 students. Research data in the form of quantitative data is then analyzed using descriptive quantitative analysis techniques. The study results were video-based learning media products in the form of mp4 files equipped with music background, animation, and narrator. Video feasibility obtained a percentage of $96.06 \%$ from media experts, and material experts obtained a percentage of $90.41 \%$ with excellent classification. From prospective users (grade 3 students) obtained a percentage of $96.66 \%$ with the classification strongly agree in using it. That way, the video-based learning media is worth using in the learning process.
\end{abstract}

Keywords: Development, Learning Media, Qurma

\begin{abstract}
Abstrak
Al-Qur'an sebagai pedoman hidup harus dimengerti kandungan makna nya. Sering kali ditemui pembelajaran materi Surat-Surat pendek berkisar pada membaca ayat, menghafal dan mengetahui artinya saja. Di MI Narrative Quran terdapat mata pelajaran Qur'an dan Makna (Qurma). Selain bisa membaca dan mengetahui artinya, peserta didik juga dituntut mampu memahami isi kandungan Al-Qur'an. Penelitian ini bertujuan untuk menciptakan sebuah produk media pembelajaran berbasis video dalam memahami Qurma Surat AlHumazah. Penelitian ini menggunakan metode Research and Development (R\&D) dengan menerapkan enam langkah, yaitu: potensi dan masalah, pengumpulan data, desain produk, validasi desain, revisi desain, serta uji coba produk. Kelayakan media pembelajaran berupa video tersebut telah dinilai dengan menggunakan angket oleh ahli media, ahli materi, dan peserta didik kelas 3. Data penelitian yang diperoleh berupa data kuantitatif kemudian dianalisis dengan memakai teknik analisis deskriptif kuantitatif. Hasil
\end{abstract}


penelitian yang didapat dari penelitian ini berupa produk media pembelajaran berbasis video yang berbentuk file mp4 yang dilengkapi dengan background musik, animasi, serta narator. Kelayakan video diperoleh persentase $96.06 \%$ dari ahli media, dan dari ahli materi diperoleh persentase $90.41 \%$ dengan klasifikasi sangat baik. Dari calon pengguna (siswa kelas 3) diperoleh persentase $96.66 \%$ dengan klasifikasi sangat setuju dalam menggunakannya. Dengan begitu media pembelajaran berbasis video tersebut layak diaplikasikan dalam sebuah proses pembelajaran.

Kata Kunci: Media Pembelajaran, Pengembangan, Qurma

\section{Pendahuluan}

Perkembangan ilmu pengetahuan dan teknologi dalam waktu beberapa tahun belakangan ini telah berkembang dengan kecepatan yang sangat luar biasa. Perkembangan itu melahirkan beragam transformasi pada berbagai dimensi kehidupan manusia, termasuk dalam bidang pendidikan. Oleh sebab itu, pendidikan perlu beradaptasi agar tidak mengalami ketertinggalan. Untuk itu perlu adanya pengembangan dari segi media pembelajaran. Teknologi yang telah disediakan di berbagai macam lembaga pendidikan seharusnya dimanfaatkan guna membantu proses pembelajaran dalam pendidikan.

Pesatnya perkembangan teknologi saat ini mengindikasikan perlunya pematangan perencanaan pembelajaran secara optimal yang merujuk pada kebutuhan siswa. Proses pembelajaran yang kreatif dan inovatif, disertai bahan ajar yang menunjang, maka akan mampu meningkatkan kualitas pembelajaran, sesuai dengan perkembangan teknologi yang ada. Terdapat beraneka ragam media dan sumber belajar yang berupa audio, visual dan audiovisual, baik elektronik maupun cetak. Dengan pemanfaatan teknologi informasi dalam proses belajar mengajar, maka akan mampu menciptakan proses pembelajaran yang menarik serta bermakna bagi siswa. ${ }^{1}$

Bahan ajar yang telah dikembangkan bisa dipakai sebagai media oleh guru di dalam proses pembelajaran, dengan menyediakan ataupun memfasilitasi alat bantu pembelajaran yang berupa sebuah media, yang pastinya lebih mudah dipahami oleh semua siswa dalam menguasai materi di setiap kegiatan pembelajaran, dan dengan menambah media pembelajaran selain yang sudah ada, ataupun yang sudah dikenal

\footnotetext{
${ }^{1}$ Yeka Hendriyani et al., "Analisis Kebutuhan Pengembangan Media Pembelajaran Berbasis Video Tutorial," Jurnal Teknologi Informasi Dan Pendidikan Vol. 11, no. 2 (2018).
} 
selama ini di dalam kelas, juga harus menyediakan media pembelajaran alternatif yang mampu meningkatkan pemahaman dan motivasi belajar siswa. ${ }^{2}$

Madrasah Ibtidaiyah Narrative Quran (MINAN) berada di wilayah Kabupaten Lamongan. Madrasah ini mempunyai kekhasan tersendiri yang mengusung konsep fun learning. Perwujudan fun learning mengacu pada desain pembelajaran inovatif dengan memanfaatkan beragam model dan metode pembelajaran yang menyenangkan. Dengan cara demikian, siswa menjadi lebih banyak peluang untuk memperoleh pengalaman pembelajaran yang bermakna. Dengan begitu, siswa mampu menginternalisasikan nilainilai yang diperolehnya dari pembelajaran tersebut dengan sukarela.

Model dan metode pembelajaran yang menyenangkan juga bisa diaplikasikan dalam pembelajaran Al-Qur'an. Memahami isi kandungan Al-Qur'an dengan metode klasik tentu saja akan terasa membosankan dan menjenuhkan bagi siswa di tingkat Madrasah Ibtidaiyah generasi sekarang karena setiap generasi mempunyai karakternya sendiri. Sehingga tidak bisa fokus, serta sulit memahami materi yang telah disampaikan oleh guru. Oleh karena itu, inovasi serta kreatifitas untuk mengemas sebuah pembelajaran yang adaptif dalam pembelajaran Al-Qur'an sangatlah diperlukan dengan tetap memerhatikan gaya belajar siswa sesuai dengan kondisi zamannya.

Madrasah Ibtidaiyah Narrative Quran (MINAN) telah menghadirkan muatan lokal berupa mata pelajaran (mapel) Al-Qur'an dan Makna (Qurma). Mapel ini memiliki metode pembelajaran khas untuk menyampaikan materi pelajaran, yakni dengan mengusung konsep bercerita atau bernarasi. Orientasi mapel ini adalah pencapaian kompetensi berupa kemampuan untuk memahami isi kandungan ataupun menceritakan kisah-kisah islami yang terkandung dalam setiap suratnya. Harapannya adalah agar peserta didik mampu mengaplikasikannya didalam kehidupan seharihari.

Adalah Tim Guru Mapel Al-Qur'an dan Hadis (Qurdis) MINAN yang menyusun buku ajar Qurma. 114 Surat dalam Al-Qur'an didistribusikan pada tiap kelas yang bersumber pada urutan Surat. Materi Surat Al-Humazah adalah salah satu materi yang ada pada kelas 3. Di tiap bagian buku Qurma, setiap siswa mempelajari Al-Qur'an serta isi kandungannya. Sistematika dari buku Qurma memuat komposisi berikut ini: Bernarasi dalam Bait (Bibit Qurma), Membaca Cerita Panjang (Batang Qurma), Bukti dan Hasil (Buah Qurma), Jawaban Uraian Surat (Jus Qurma), Diskusi Ayat Narasi

2 Muhammad Munir, “Analisis Pengembangan Media Pembelajaran Pengolah Angka (Spreadsheet) Berbasis Video Screencast,” Jurnal Pendidikan Teknologi Dan Kejuruan Volume 21, no. 4 (2013). 
(Daun Qurma), Alkisah dalam Karangan (Akar Qurma), Penulisan Lafan Hafalan (Pelepah Qurma).

Komposisi buku Qurma merupakan sebuah inovasi yang lahir sebagai upaya menciptakan fun learning yang berorientasi pada kemampuan narasi dan literasi. Pada awal pembahasan setiap Surat, melalui Bibit Qurma, anak-anak diajak bernyanyi. Bibit Qurma merupakan lirik serta lagu yang disusun berdasarkan informasi umum Surat, seperti; nama dan nomor Surat, jumlah ayat, kategori Makkiyah-Madaniyah, serta sekilas tentang isi kadungan yang termuat di dalam Surat. Dari sinilah guru dituntut mampu berinovasi dan kreatif dalam mengemas pembelajaran baik melalui metode, model maupun pengembangan media pembelajarannya, agar mampu mencapai tujuan dari pembelajaran sesuai dengan yang diharapkan.

Dari uraian di atas, maka bagian selanjutnya dari tulisan ini memfokuskan pada pengembangan media pembelajaran berbasis video pada mata pelajaran Qurma Surat Al-Humazah. Tujuan dari penelitian ini adalah menghasilkan produk berupa media pembelajaran berbasis video pada mata pelajaran Qurma materi Surat Al-Humazah. Peneliti memilih media berupa video sebagai media pembelajaran yang perlu dikembangkan, karena media berupa video sangat relatif lebih mudah dalam pengoperasiannya. Adapun isi ataupun materi dari media pembelajaran yang dikembangkan ialah pembacaan Surat Al-Humazah, beserta arti tiap ayat, asbabun nuzul dan isi kandungannya, yang juga dilengkapi dengan musik pengantar, animasi dan juga narator.

\section{Metode}

Penelitian ini menggunakan metode penelitian dan pengembangan/research and development (R\&D). Penelitian ini mengembangkan media pembelajaran berbasis video pada mata pelajaran Qurma materi Surat Al-Humazah. Langkah-langkah penelitian mengikuti model pengembangan Sugiyono yang mencakup sepuluh langkah. ${ }^{3}$ Akan tetapi karena keterbatasan peneliti, serta terdapat satu kali revisi yang mana dalam penelitian ini digunakan untuk skala kecil, maka rancangan kegiatan dalam penelitian ini hanya sampai pada langkah ke enam yaitu: (1) potensi dan masalah; (2) pengumpulan data; (3) desain produk; (4) validasi desain mencakup; (5) revisi desain; (6) uji coba produk. ${ }^{4}$ Subyek dari penelitian tersebut ialah peserta

\footnotetext{
${ }^{3}$ Sugiyono, Metode Penelitian Kuantitatif, Kualitatif, Dan R\&D, Cetakan Ke (Bandung: Alfabeta, 2017).

${ }^{4}$ Sugiyono.
} 
didik kelas 3 MINAN Lamongan, tahun pembelajaran 2020/2021. Prosedur penggunaan pada metode Research and Development (R\&D) yang dipaparkan pada gambar berikut:

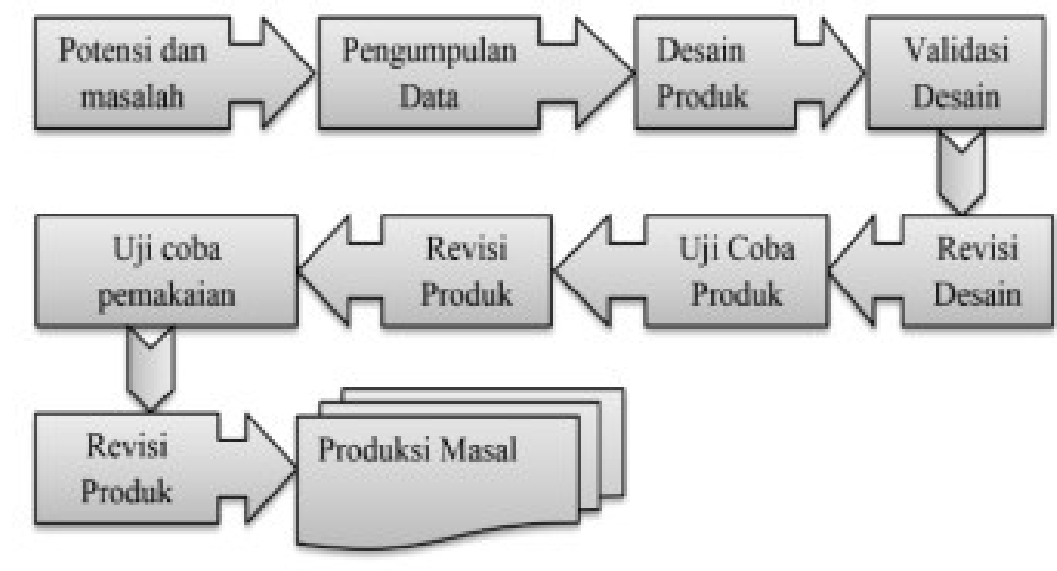

Gambar 1. Tahapan metode Research and Development (R\&D)

Potensi dan masalah, langkah ini adalah langkah yang digunakan untuk melihat potensi dan juga problem yang ada, yang mana dilakukan dengan metode observasi. Observasi dilakukan pada saat melakukan pembelajaran tatap muka di kelas 3 MINAN Lamongan. Data yang dikumpulkan dalam langkah pengumpulan data antara lain adalah: materi bahan ajar, RPP, gambar serta jobsheet Surat Al-Humazah. Data didapatkan dari Dokumen Kurikulum MINAN, buku Qurma, maupun buku 114 AlQur'an stories. Setelah mendapatkan data, selanjutnya data yang dipilih disesuaikan dengan KI dan KD mata pelajaran Qurma pada materi ajar Surat Al-Humazah.

Desain produk, langkah ini adalah langkah perancangan kerangka sebuah produk media pembelajaran berbasis video yang nantinya akan dikembangkan. Sementara produk media pembelajaran berbasis video dibuat dengan tiga tahapan yang mencakup: 1) pra produksi, yang terdiri dari identifikasi masalah, pembuatan naskah dan juga pembuatan storyboard, 2) produksi, dalam tahapan ini dilakukan kegiatan shooting ataupun rekaman yang berkaitan dengan membaca, mengartikan per ayat, asbabun nuzul dan penjelasan dari Surat Al-Humazah, 3) pasca produksi, dalam tahapan ini dilakukan editing video serta finalisasi video atau mastering.

Validasi desain, pada langkah ini dilakukan uji kalayakan media. Yang mana media pembelajaran telah diujikan kepada ahli media dan ahli materi pembelajaran. Uji validitas dilaksanakan guna mengetahui dan juga mengevaluasi dari media yang telah dikembangkan, agar sesuai dengan tujuan pembelajaran yang diharapkan.

Uji coba produk, langkah tersebut dilakukan guna memperoleh respon dari peserta didik terhadap media pembelajaran yang telah dikembangkan. Pengambilan 
data dilakukan pada 13 peserta didik kelas 3 MINAN dengan menggunakan instrumen berupa angket atau kuesioner dan peneliti memberikan 1 kali tes yaitu tes hasil belajar dari pemakaian video pembelajaran tersebut.

Data yang diambil adalah data hasil validasi ahli media, ahli materi, serta peserta didik. Instrumen yang telah digunakan berupa kuesioner siswa dan lembar validasi ahli. Dalam teknik pengumpulan data dilakukan dengan cara observasi pada tahap potensi dan juga masalah, dokumentasi dalam tahap pembuatan media serta kuesioner untuk mendapatkan respon penilaian peserta didik.

Skala pengukuran dengan menggunakan skala likert. Adapun kriteria penilaian jawaban dari setiap item instrumen dengan skala likert yang mempunyai bobot penilaian antara 1-4 dengan kategori penilaian berupa kurang baik, cukup baik, baik, dan juga sangat baik pada instrumen penilaian ahli media, dan ahli materi, sementara di instrumen respon peserta didik menggunakan kategori penilaian berupa sangat tidak setuju, tidak setuju, setuju, dan juga sangat setuju. Teknik analisis data yang diaplikasikan didalam penelitian tersebut ialah teknik analisis deskriptif kuantitatif. Persentase dihitung dengan menggunakan rumus sebagai berikut:

$$
\text { Persentase }=\frac{\text { Skor yang diperoleh }}{\text { Skor yang diharapkan }} \times 100 \%
$$

Persentase kelayakan yang dimaksudkan adalah untuk mengetahui status tingkat interpretasi variabel seperti dalam tabel berikut ini:

\begin{tabular}{|c|c|c|}
\hline Persentase Pencapaian (\%) & Skala Nilai & Interpretasi \\
\hline $76-100$ & 4 & Sangat Baik \\
\hline $51-75$ & 3 & Baik \\
\hline $26-50$ & 2 & Cukup Baik \\
\hline $0-25$ & 1 & Kurang Baik \\
\hline
\end{tabular}

Tabel 1. Tabel Skala Persentase

Tabel skala persentase tersebut digunakan untuk menentukan nilai dari kelayakan produk yang dihasilkan. Adapun nilai kelayakan untuk produk pengembangan media pembelajaran berbasis video pada mata pelajaran Qurma, materi Surat Al-Humazah tersebut ditetapkan kriteria kelayakan minimal sangat baik ataupun mencapai persentase minimal $76 \%$. 


\section{Pengembangan Media Pembelajaran..., Siti M, A. Hamid, Rudy A.H, M. Salehudin}

\section{Pembahasan}

\section{Konsep Pengembangan Media Pembelajaran}

Dalam Kamus Besar Bahasa Indonesia (KBBI) pengembangan berarti proses, cara, perbuatan mengembangkan, ${ }^{5}$ berupa perbuatan yang menjadikan bertambah, berubah sempurna pemikiran, pengetahuan, dan sebagainya. ${ }^{6}$ Kegiatan pengembangan meliputi perencanaan, pelaksanaan, dan evaluasi yang dilanjutkan dengan melakukan penyempurnaan sehingga diperoleh model yang diharapkan. Sedangkan media pembelajaran adalah segala sesuatu yang dapat menyalurkan atau menyampaikan pesan dari suatu sumber secara terencana sehingga terjadi lingkungan belajar kondusif dimana penerimanya dapat melakukan proses belajar secara efesien dan efektif serta merupakan bentuk fisik yang digunakan pendidik untuk penyajian pesan dan memfasilitasi setiap siswa dalam mencapai tujuan pembelajaran. ${ }^{7}$ Sehubungan dengan definisi itu, Wina Sanjaya menyatakan bahwa media pembelajaran ialah segala sesuatu yang meliputi alat, lingkungan serta semua bentuk kegiatan yang dikemas guna menambah pengetahuan, merubah sikap dan juga menanamkan sebuah keterampilan kepada setiap orang yang mau memanfaatkannya. ${ }^{8}$ Dengan demikian, media pembelajaran dapat diartikan segala sesuatu yang bisa dipakai untuk menyalurkan sebuah pesan, dari pengirim kepada penerima sehingga mampu merangsang perasaan, pikiran, perhatian serta minat siswa dengan sedemikian rupa yang menjadikan proses belajar terjadi. ${ }^{9}$

Media pembelajaran memiliki peran yang sangat penting bagi keberlangsungan proses belajar mengajar, sebab mampu menciptakan suasana belajar menjadi lebih hidup lagi serta bermakna. ${ }^{10}$ Media pembelajaran memberikan banyak manfaat dalam sebuah proses belajar siswa di antaranya adalah: (1) pengajaran yang lebih menarik dan menjadikan perhatian siswa sehingga mampu menumbuhkan motivasi belajar siswa; (2) materi ataupun bahan pelajaran akan terlihat lebih jelas maknanya dan para siswa bisa lebih memahaminya; (3) metode mengajar akan banyak variasi; (4) Siswa akan

\footnotetext{
${ }^{5}$ Kamus Besar Bahasa Indonesia (Jakarta: Pusat Bahasa, Departemen Pendidikan Nasional Indonesia, 2014).

6 Sukiman, Pengembangan Media Pembelajaran (Sleman Yogyakarta: PT Pustaka Insan Madani, Anggota IKAPI, 2012).

${ }^{7}$ Muhammadd Yaumi, Media Dan Teknologi Pembelajaran (Jakarta: Prenadamedia Group, 2018).

${ }^{8}$ Wina Sanjaya, Media Komunikasi Pembelajaran (Jakarta: Prenadamedia Group, 2012).

9 Muhammad Aziz Fauzan and Dwi Rahdiyanta, "Pengembangan Media Pembelajaran Berbasis Video Pada Teori Pemesinan Frais," Jurnal Dinamika Vokasional Teknik Mesin 2, no. 2 (2017): 82, https://doi.org/10.21831/dinamika.v2i2.15994.

10 Munir, "Analisis Pengembangan Media Pembelajaran Pengolah Angka (Spreadsheet) Berbasis Video Screencast.".
} 
lebih sering melakukan kegiatan belajar, dikarenakan siswa tidak hanya mendengarkan saja, melainkan siswa dapat mengamati, melakukan, dan mendemonstrasikan. ${ }^{11}$

Penggunaan media pembelajaran dalam proses belajar-mengajar mampu membangkitkan keinginan dan minat baru, rangsangan proses pembelajaran, bahkan dapat membawa pengaruh psikologis terhadap peserta didik. Maka dari itu, media pembelajaran dalam bidang pendidikan seharusnya disesuaikan dengan materi atau bahan ajar yang digunakan, agar penggunaannya menjadi lebih proporsional. Seperti yang kita ketahui bahwa media pembelajaran saat ini mengalami pengembangan yang sangat luar biasa. ${ }^{12}$ Ditinjau dari perkembangannya, media pembelajaran dapat dikategorisasikan menjadi dua jenis yaitu media pembelajaran konvensional dan media pembelajaran digital. Media digital di sini mengacu pada semua bentuk media baik berupa gambar, audio, video, audiovisual, video interaktif atau pemanfaatan software atau aplikasi tertentu seperti microsoft power point, macromedia, movie maker, game edukatif, dan sebagainya. ${ }^{13}$

Pengembangan berbagai bentuk media pembelajaran merupakan suatu usaha untuk menyusun program media pembelajaran yang ditujukan untuk perencanaan media. Media yang akan diaplikasikan dalam proses pembelajaran terlebih dahulu direncanakan serta dirancang yang sesuai dengan kebutuhan siswa serta lapangan, dan juga disesuaikan dengan karakteristik dari materi pembelajaran. ${ }^{14}$ Pengembangan media pembelajaran merupakan serangkaian proses atau kegiatan yang dilakukan guna menghasilkan suatu media pembelajaran berdasarkan teori pengembangan pembelajaran yang sudah ada.

Dari berbagai macam media yang ada, media yang disukai oleh siswa pada saat ini ialah media pembelajaran yang berbasis multimedia. Pembelajaran berbasis multimedia merupakan kegiatan pembelajaran yang menggunakan ataupun memanfaatkan komputer untuk menciptakan serta menggabungkan teks, audio, grafik, gambar bergerak (video dan animasi) melalui penggabungan link serta tool yang

\footnotetext{
${ }^{11}$ Nana Sudjana and Ahmad Rivai, Media Pengajaran (Bandung: Sinar Baru Algensindo., 2013).

${ }^{12}$ Ani Cahyadi, "Pengembangan Media Dan Sumber Belajar Teori Dan Prosedur," Jakarta: PT. Prestasi Pusta Karya, no. January 2018 (2019): 1-9.

${ }^{13}$ Edi Nurhidin, "Inovasi Pembelajaran Pendidikan Agama Islam (PAI) Melalui Pemanfaatan Media Pembelajaran Kontekstual Dan Pengembangan Budaya Religius Di Sekolah,” KUTTAB 1, no. 1 (March 31, 2017): 1-14, https://doi.org/10.30736/kuttab.v1i1.95.

14 Abrar Hafizh and Ridho Bayu Yefterson, "Pengembangan Media Pembelajaran Berbasis Video Menggunakan Windows Movie Maker Dalam Pembelajaran Sejarah (Materi Pelajaran: Awal Masuk Dan Berkembang Agama Islam Di Indonesia)," Jurnal Halaqah Vol. 1, no. 3 (2019): 224-45, https://doi.org/10.5281/zenodo.3361710.
} 


\section{Pengembangan Media Pembelajaran..., Siti M, A. Hamid, Rudy A.H, M. Salehudin}

memungkinkan pengguna untuk melakukan navigasi, berkreasi, berinteraksi, dan berkomunikasi dari berbagai macam bentuk media pembelajaran. ${ }^{15}$ Keberadaan video dalam kehidupan sekarang tentu bukan hal yang asing. Di mana pada setiap aplikasi dan media sosial yang kita gunakan baik melalui smartphone/laptop/personal computer pasti menemukan berbagai bentuk video. Bahkan dalam masa pandemi saat ini, sering kali peneliti melihat anak-anak usia sekolah dasar disekitar lingkungan rumah, mereka kemana-mana selalu membawa Smartphone serta yang ditonton adalah berbasis video, dan dari hasil komunikasi dengan anak-anak, diperoleh informasi bahwa anak-anak begitu antusias, merasa senang dan tertarik dengan media video.

Adapun media pembelajaran berbasis video ialah media yang menampilkan ataupun menyajikan audio dan visual atau kombinasi keduanya yang berisi pesan-pesan pembelajaran seperti konsep, prinsip, prosedur, dan teori. Penggunaannya adalah untuk membantu siswa dalam memahami materi pelajaran. ${ }^{16}$ Dalam hal ini, video juga berarti teknologi penangkapan, perekaman, pengolahan, serta penyimpanan, pemindahan, dan juga perekonstruksian urutan sebuah gambar diam dengan menyajikan ataupun menampilkan adegan-adegan di dalam gerak secara elektronik. ${ }^{17}$ Menurut Fadhli, video adalah gambar yang bergerak. Apabila objek dalam animasi tersebut adalah buatan, maka objek dalam video tersebut adalah nyata. ${ }^{18}$

Dengan melihat kemajuan teknologi serta perkembangan sosial budaya yang terdapat di negara kita saat ini, menonton ataupun menyaksikan video merupakan sebuah aktifitas yang bisa dilakukan oleh seluruh kalangan. Video yang dimaksud di dalam penelitian ini ialah gambar hidup yang memiliki tampilan visual serta audio, pada saat ini video telah mengalami perkembangan yang sangat pesat seiring dengan perkembangan teknologi yang sudah ada. Video mempunyai berbagai peran, selain video sebagai sarana hiburan, video juga bisa berfungsi sebagai media pembelajaran. Tujuan penggunaan video dalam proses pembelajaran adalah untuk mengembangkan dan meningkatkan kemampuan kognitif, dengan memberikan suatu rangsangan

\footnotetext{
${ }^{15}$ Magfirah Rasyid, Andi Asmawati Azis, and Andi Rahmat Saleh, "Pengembangan Media Pembelajaran Berbasis Multimedia Dalam Konsep Sistem Indera Pada Siswa Kelas XI SMA," Jurnal Pendidikan Biologi Volume 7, no. 2 (2016): 69-80.

${ }^{16}$ Dewi Ayu Sulistya, "Pengembangan Quantum Teaching Berbasis Video Pembelajaran Camtasia Pada Materi Permukaan Bumi Dan Cuaca," Profesi Pendidikan Dasar 1, no. 2 (2018): 169, https://doi.org/10.23917/ppd.v1i2.5067.

${ }^{17}$ Munir, Multimedia : Konsep \& Aplikasi Dalam Pendidikan (Bandung: Alfabeta, 2012).

${ }^{18}$ Muhibuddin Fadhli, "Pengembangan Media Pembelajaran Berbasis Video Kelas Iv Sekolah Dasar," Jurnal Dimensi Pendidikan Dan Pembelajaran 3, no. 1 (2015): 24-29, https://doi.org/10.24269/dpp.v3i1.157.
} 
berbentuk gambar bergerak serta suara, dan menyampaikan pesan untuk mempengaruhi sikap serta emosi. Berdasarkan tujuan tersebut, manfaat media video dalam proses pembelajaran yaitu berguna untuk menarik atensi peserta didik pada saat menyampaikan materi ajar, menumbuhkan serta meningkatkan motivasi belajar peserta didik, dan membagikan pengalaman belajar dengan menyimpulkan atau merumuskan pembelajaran dari sebuah video yang disajikan. ${ }^{19}$

Namun terdapat pula problem yang dialami selama pemanfaatan video sebagai media pembelajaran, yaitu: terlalu cepat dalam penyampaian materi, kurang terperinci, sehingga materi yang disampaikan kurang detail. Dalam pembuatan videopun dibutuhkan waktu yang cukup lama, karena melalui proses produksi dengan beberapa tahapan yang cukup banyak. Proses perencanaan diawali dengan membuat storyboard, menulis skenario dan juga merencanakan pengambilan gambar. Pekerjaan utama dalam produksi video ialah proses pengambilan gambar dengan menggunakan perekam video, baik menggunakan bentuk analog maupun digital. Proses akhir meliputi kegiatan capturing, editing dan juga finishing, yang lebih bersifat pada pengaturan data mentah, untuk diolah menjadi video utuh yang sesuai kebutuhan. ${ }^{20}$

Filosofi mengajar yang baik bukan hanya sekedar menransfer pengetahuan kepada peserta didik, melainkan cara membantu peserta didik dapat belajar dan menyerap ilmu dengan maksimal. Dengan demikian proses pembelajaran yang baik adalah proses pembelajaran yang memberikan kesempatan kepada peserta didik untuk mencari, menemukan, dan memecahkan masalah secara langsung dari pengalaman belajarnya. Interaksi seorang pendidik dengan peserta didik menjadi unsur yang sangat penting karena dalam proses pembelajaran, peserta didik harus ditempatkan sebagai subjek belajar. Belajar adalah proses perubahan pada diri peserta didik yang ditandai adanya perubahan tingkah laku, pemahaman, pengetahuan, serta pada aspek yang lainnya. ${ }^{21}$ Untuk mencapai itu semua perlu dilakukan pengembangan media pembelajaran terkait materi ajar.

\footnotetext{
${ }^{19}$ Ayu Fitria, "Penggunaan Media Audio Visual Dalam Pembelajaran Anak Usia Dini," Jurnal Cakrawala Dini Vol. 5, no. 2 (2014): 57-62.

${ }^{20}$ Indra Aditya, "Pemanfaatan Video Pembelajaran Sebagai Sumber Belajar Bagi Siswa Kelas 1 Program Studi Teknik Bangunan Gedung Di SMK Negeri 2 Surakarta (Pada Mata Pelajaran Praktek Batu)" (Skripsi, Universitas Sebelas Maret Surakarta, 2011).

${ }^{21}$ Winarto Eka Wahyudi, "Radikalisme Dalam Bahan Ajar Dan Analisa Wacana Kritis Perspektif Van Dijk Terhadap Materi PAI Tingkat SMA," JALIE: Journal of Applied Linguistics and Islamic Education Volume 01, no. 01 (2017): 1-20.
} 


\section{Pengembangan Media Pembelajaran Video pada Pembelajaran Qurma di MI Narrative Quran Lamongan}

Teknologi pendidikan bisa saja didefinisikan sebagai sebuah teori serta praktik dalam merancang, memanfaatkan, mengembangkan, mengelola, dan menilai proses, serta sumber untuk belajar. ${ }^{22}$ Rancangan media pembelajaran berdasarkan pada teori kontruktivistis di antaranya media pembelajaran berisi informasi yang memberikan pengalaman berharga, memotivasi siswa melakukan aktifitas, dan menstimulus siswa untuk berpikir konsep teori. ${ }^{23}$ Pengembangan media pembelajaran yang tepat akan mengefektifkan proses pembelajaran dan diperoleh hasil belajar sesuai tujuan pembelajaran yang diharapkan.

Pengertian pengembangan media pembelajaran yang dimaksud ialah suatu usaha penyusunan program media pembelajaran yang lebih berpusat pada perencanaan media. Sebuah perencanaan media didasarkan oleh kebutuhan peserta didik. Salah satu indikator adanya suatu kebutuhan dikarenakan di dalamnya terdapat kesenjangan. Kesenjangan ialah terdapat ketidaksesuaian antara apa yang seharusnya dan apa yang terjadi. Dalam pembelajaran yang dimaksud kebutuhan ialah adanya kesenjangan antara kemampuan, keterampilan, serta sikap yang dimiliki oleh peserta didik. ${ }^{24}$

Dalam pengembangan media pembelajaran berbasis video mata pelajaran Qurma materi Surat Al-Humazah ini, produk yang dihasilkan berupa video pembelajaran. Pembuatan media pembelajaran berbasis video tersebut bertujuan untuk memberikan penjelasan dan pemahaman yang lebih rinci kepada pihak yang akan menggunakannya. Sebagai penunjang keberhasilan pembelajaran, penggunaan strategi dan media yang tepat sangat dibutuhkan, karena juga dapat memberikan tambahan wawasan serta ilmu pengetahuan bagi siswa melalui pemanfaatan media teknologi. ${ }^{25}$

Produk tersebut menyuguhkan materi yang telah dikembangkan yaitu: bacaan Surat Al-Humazah, kemudian dilanjut dengan arti dari tiap ayat Surat Al-Humazah, diperjelas melalui cerita asbabun nuzul dan penjelasan dari Surat Al-Humazah, serta disimpulkan dengan kemasan lagu bibit Qurma dari Surat Al-Humazah, dan diakhiri

22 Arbain Nurdin, "Inovasi Pembelajaran Pendidikan Agama Islam Di Era Information and Communication Technology," TADRIS: Jurnal Pendidikan Islam 11, no. 1 (2016): 49, https://doi.org/10.19105/tjpi.v11i1.971.

23 Dr. Husniyatus Salamah Zainiyati M.Ag, Pengembangan Media Pembelajaran Berbasis ICT Konsep Dan Aplikasi Pada Pembalajaran PAI (Jakarta: Kencana, 2017).

24 Dwi Puspitarini, Media Pembelajaran Pemilihan, Penggunaan, Pengembangan (Jember: STAIN PRESS, 2013).

25 Himatul Ulya, Noer Hidayatul Laily, and Mukhammad Luqman Hakim, "Pengembangan Media Pembelajaran Pai Dengan Menggunakan Video Explanasi, Pop Up Dan Kahoot," Edudeena: Journal of Islamic Religious Education Vol. 4, no. 1 (2020): 39-48. 
dengan kalimat bijak yang berupa motivasi. Semua itu tersusun dengan rapi dalam video dan disajikan dengan desain semenarik mungkin. Hal pertama yang harus dilakukan untuk membuat video pembelajaran tersebut ialah mempersiapkan alat serta materi yang diperlukan. Pembuat haruslah menguasai betul tentang materi yang akan dijelaskan. ${ }^{26}$

Media berbasis video tersebut telah di desain dengan mengaplikasikan prinsipprinsip pengembangan yang memperhatikan berbagai aspek dan mampu mempengaruhi keberhasilan pembelajaran. Dengan harapan untuk menjadikan siswa lebih termotivasi dalam belajar, optimalisasi potensi raga serta jiwa siswa ketika pembelajaran berlangsung. Serta bisa dipergunakan sesuai dengan tingkat kecepatan berpikir siswa dalam memahami materi dan kebutuhannya. ${ }^{27}$

Proses pembuatan media pembelajaran berbasis video menggunakan beberapa langkah. Diawali dengan membuat naskah ataupun bahan materi yang diambil dari berbagai sumber belajar tentang Surat Al-Humazah, yang mengacu pada Kompetensi Inti (KI), Kompetensi Dasar (KD), dan Indikator yang sudah ditentukan. Kemudian rekam suara melalui media tafeware camcoder, dan shooting menggunakan rekam video yang terdapat di smartphone. Diakhiri dengan proses editting, menggunakan perpaduan antara media Power Point, aplikasi video scribe dan kinemaster, agar bisa menambahkan teks, audio atau narasi, animasi bergerak, dan juga backsound atau musik instrumen. Dengan tujuan agar pengguna merasa lebih rileks serta tidak jenuh, ketika mempelajari keseluruhan isi materi di dalam video. Sehingga dapat mempermudah pemahaman siswa dan meningkatkan ketertarikan pada pembelajaran. ${ }^{28}$

Dari hasil survei, video pembelajaran ini berbeda dengan video pembelajaran materi Surat Al-Humazah yang sudah ada di konten youtube. Karena isi maupun materi dalam video ini sangat luas ataupun mencakup semua materi, yang disertai lagu Bibit Qurma dari Surat Al-Humazah dan menyuguhkan tampilan yang sangat menarik, diiringi backsound yang sesuai dengan isi maupun materi dalam video tersebut.

Video pembelajaran ini sangat praktis, karena berbentuk file mp4 sehingga video ini bisa langsung digunakan melalui berbagai macam gadget, seperti

\footnotetext{
${ }^{26}$ Munir, “Analisis Pengembangan Media Pembelajaran Pengolah Angka (Spreadsheet) Berbasis Video Screencast.".

${ }^{27}$ Tri Cipto Tunggul Wardoyo and MT. Faqih Ma'arif, "Pengembangan Media Pembelajaran Berbasis Video Animasi Pada Mata Pelajaran Mekanika Teknik Di SMK Negeri 1 Purworejo,” Jurnal Pendidikan Teknik Sipil Dan Perencanaan 3, no. 3 (2015): 1-7.

${ }^{28}$ R. Arifin, "Media Pembelajaran Berbasis Video Animasi Pada Mata Kuliah Logika Dan Algoritma 1," Bina Insani ICT Journal 4, no. 1 (2017): 83-94.
} 
smartphone, netbook, komputer maupun laptop. File video pembelajaran yang dikembangkan sebesar $174 \mathrm{MB}$ itu sangat mudah dijalankan, meskipun menggunakan komputer dengan spesifikasi rendah dan juga bisa diakses dikonten media youtube. Selain itu, media pembelajaran berbasis video tersebut juga sangat mudah digunakan, karena dalam mengaplikasikannya tidak perlu keahlian khusus tidak memerlukan software khusus. Untuk orang awam yang dirasa belum terampil dalam menggunakan gadget juga tidak memerlukan waktu yang lama untuk mempelajarinya. Pada saat media sudah dijalankan atau dioperasikan, maka materi yang ada dalam media video tersebut akan terus berjalan seperti pemutaran video pada umumnya. Apabila terdapat materi yang dirasa penting untuk dipelajari dan ingin menghentikan video, maka operator cukup menekan tombol pause yang ada pada software pemutar video ataupun menekan "spasi" pada keyboard. ${ }^{29}$

Kelayakan media pembelajaran berbasis video mata pelajaran Qurma materi Surat Al-Humazah diujikan melalui tahap validasi ke ahli media dan ahli materi. Kemudian video pembelajaran tersebut ditindaklanjuti sebagai perbaikan serta diujicobakan kepada peserta didik kelas 3 Madrasah Ibtidaiyah Narrative Quran Lamongan yang berjumlah 13 siswa dengan memaka instrumen angket respon peserta didik yang sudah valid untuk memperoleh hasil penilaian berdasarkan respon peserta didik tersebut.

Penilaian kelayakan media pembelajaran berbasis video mata pelajaran Qurma materi Surat Al-Humazah dilakukan oleh ahli media dan dinilai berdasarkan 6 aspek yakni, aspek kesesuaian dengan karakteristik peserta didik, tampilan media, keefektifan, efisiensi, kualitas, dan keamanan. Berikut ini data hasil penilaian ahli media:

\begin{tabular}{|c|l|c|c|}
\hline No. & \multicolumn{1}{|c|}{ Aspek } & $\begin{array}{c}\text { Persentase } \\
(\mathbf{\%})\end{array}$ & Klasifikasi \\
\hline 1. & Kesesuaian dengan karakteristik peserta didik & 87.5 & Sangat Baik \\
\hline 2. & Tampilan Media & 88.88 & Sangat Baik \\
\hline 3. & Keefektifan & 100 & Sangat Baik \\
\hline 4. & Efisiensi & 100 & Sangat Baik \\
\hline 5. & Kualitas & 100 & Sangat Baik \\
\hline 6. & Keamanan $\quad 100$ & Sangat Baik \\
\hline \multicolumn{2}{r|}{ Rata-rata } & 96.06 & Sangat Baik \\
\hline
\end{tabular}

Tabel 2. Hasil Penilaian Tiap Aspek oleh Ahli Media

${ }^{29}$ Imam Mustholiq and dkk, "Pengembangan Media Pembelajaran Interaktif Berbasis Multiedia Pada Mata Kuliah Dasar Listrik.," Jurnal Pendidikan Teknologi Dan Kejuruan Vol. 16, no. 1 (2007): 1-18. 
Hasil persentase kelayakan media pembelajaran berbasis video yang diperoleh dari ahli media untuk aspek kesesuaian dengan karakteristik peserta didik adalah sebesar $87.5 \%$ termasuk pada klasifikasi sangat baik, untuk tampilan media sebesar $88.88 \%$ termasuk pada klasifikasi sangat baik, untuk keefektifan sebesar $100 \%$ termasuk pada klasifikasi sangat baik, untuk efisiensi sebesar $100 \%$ termasuk pada klasifikasi sangat baik, untuk kualitas sebesar 100\% termasuk pada klasifikasi sangat baik, dan untuk keamanan sebesar 100\% termasuk pada klasifikasi sangat baik. Dan hasil penilaian dari ahli media untuk penilaian semua aspek diperoleh hasil sebesar $96.06 \%$ dengan klasifikasi sangat baik, sehingga dapat disimpulkan bahwa media pembelajaran berbasis video mata pelajaran Qurma materi Surat Al-Humazah dinyatakan layak ataupun dapat digunakan untuk proses pembelajaran.

Penilaian kelayakan media pembelajaran berbasis video mata pelajaran Qurma materi Surat Al-Humazah dilakukan oleh ahli materi dan dinilai berdasarkan 4 aspek yaitu, aspek kelayakan isi, sistematika, tata bahasa, dan hakikat kontekstual. Data hasil penilaian ahli materi seperti dalam tabel berikut ini:

\begin{tabular}{|c|l|c|l|}
\hline No. & \multicolumn{1}{|c|}{ Aspek } & $\begin{array}{c}\text { Persentase } \\
(\%)\end{array}$ & Klasifikasi \\
\hline 1. & Kelayakan isi & 82.5 & Sangat Baik \\
\hline 2. & Sistematika & 100 & Sangat Baik \\
\hline 3. & Tata bahasa & 87.5 & Sangat Baik \\
\hline 4. & Hakikat kontekstual & 91.66 & Sangat Baik \\
\hline \multicolumn{2}{|c|}{ Rata-rata } & 90.41 & Sangat Baik \\
\hline
\end{tabular}

Tabel 3. Hasil Penilaian Tiap Aspek oleh Ahli Materi

Hasil persentase kelayakan media pembelajaran berbasis video yang diperoleh dari ahli materi untuk aspek kelayakan isi adalah sebesar $82.5 \%$ termasuk pada klasifikasi sangat baik, untuk sistematika sebesar 100\% termasuk pada klasifikasi sangat baik, untuk tata bahasa sebesar $87.5 \%$ termasuk pada klasifikasi sangat baik, dan untuk hakikat kontekstual sebesar $91.66 \%$ termasuk pada klasifikasi sangat baik. Dan hasil penilaian dari ahli materi untuk penilaian semua aspek diperoleh hasil sebesar $90.41 \%$ dengan klasifikasi sangat baik, sehingga dapat disimpulkan bahwa media pembelajaran berbasis video mata pelajaran Qurma materi Surat Al-Humazah dinyatakan layak ataupun dapat digunakan untuk proses pembelajaran. 
Media pembelajaran berbasis video mata pelajaran Qurma materi Surat AlHumazah, diujicobakan kepada 13 siswa kelas 3 Madrasah Ibtidaiyah Narrative Quran Lamongan, untuk memperoleh respon penilaian peserta didik dan terdiri dari 3 aspek yaitu aspek ketertarikan, materi serta bahasa. Data hasil penilaian respon peserta didik seperti dalam tabel berikut ini:

\begin{tabular}{|c|l|c|c|}
\hline No. & \multicolumn{1}{|c|}{ Aspek } & Persentase (\%) & Klasifikasi \\
\hline 1. & Ketertarikan & 100 & Sangat Setuju \\
\hline 2. & Materi & 90 & Sangat Setuju \\
\hline 3. & Bahasa & 100 & Sangat Setuju \\
\hline \multicolumn{2}{|r|}{ Rata-rata } & 96.66 & Sangat Setuju \\
\hline
\end{tabular}

Tabel 4. Hasil Penilaian Tiap Aspek oleh Peserta Didik

Hasil persentase kelayakan media pembelajaran berbasis video yang diperoleh dari respon penilaian peserta didik untuk aspek ketertarikan adalah sebesar $100 \%$ termasuk pada klasifikasi sangat setuju, untuk materi sebesar $90 \%$ termasuk pada klasifikasi sangat setuju, dan untuk bahasa sebesar $100 \%$ termasuk pada klasifikasi sangat setuju. Dan hasil penilaian dari respon peserta didik untuk penilaian semua aspek diperoleh hasil sebesar 96.66\% dengan klasifikasi sangat setuju, sehingga dapat disimpulkan bahwa media pembelajaran berbasis video mata pelajaran Qurma materi Surat Al-Humazah dinyatakan layak atau dapat digunakan untuk proses ipembelajaran.

Rata-rata persentase dari pencapaian hasil validasi ahli media, ahli materi, dan hasil penilaian dari peserta didik terhadap media pembelajaran berbasis video mata pelajaran Qurma materi Surat Al-Humazah seperti dalam tabel berikut ini:

\begin{tabular}{|c|l|c|c|}
\hline No. & \multicolumn{1}{|c|}{ Aspek } & Persentase (\%) & Klasifikasi \\
\hline 1. & Ahli media & 96.06 & Sangat Baik \\
\hline 2. & Ahli materi & 90.41 & Sangat Baik \\
\hline 3. & Respon siswa & 96.66 & Sangat Baik \\
\hline & Rata-rata & 94.37 & Sangat Baik \\
\hline
\end{tabular}

Tabel 5. Hasil Rata-rata Total Penilaian Media Video Pembelajaran

Hasil persentase kelayakan media pembelajaran berbasis video yang diperoleh dari validasi ahli media sebesar 96.06\% termasuk pada klasifikasi sangat baik, untuk hasil validasi ahli materi sebesar $90.41 \%$ termasuk pada klasifikasi sangat baik, dan untuk respon siswa diperoleh sebesar $96.66 \%$ termasuk 
pada klasifikasi sangat baik. Jadi, rata-rata total penilaian media pembelajaran berbasis video tersebut diperoleh sebesar $94.37 \%$ dengan klasifikasi sangat baik, sehingga dapat disimpulkan bahwa media pembelajaran berbasis video mata pelajaran Qurma materi Surat Al-Humazah dinyatakan layak ataupun dapat digunakan untuk proses pembelajaran.

Hasil yang diperoleh dari penelitian menunjukkan bahwa, guru sebenarnya memiliki keinginan yang besar untuk membuat dan mengembangkan sebuah media pembelajaran inovatif dan efektif, yang mampu merangsang kreatifitas serta keaktifan berfikir dan meningkatkan prestasi belajar siswa. ${ }^{30}$

\section{Penutup}

Penelitian bertujuan untuk menciptakan sebuah produk media pembelajaran berbasis video dalam memahami Qurma Surat Al-Humazah. Agar dapat memberikan penjelasan dan pemahaman yang lebih rinci kepada pihak yang akan menggunakannya. Media pembelajaran tersebut menjadi solusi maupun alternatif dalam penyajian materi, supaya tidak menjenuhkan, tidak membosankan, tidak monoton dan meningkatkan semangat siswa dalam memperhatikan materi pembelajaran. Video pembelajaran itu juga menjadi solusi bagi siswa yang tertinggal pada materi Surat Al-Humazah, karena dengan video, siswa bisa mengunduhnya pada tautan atau file yang sudah diberikan, dan juga bisa memutar video berulang-ulang dimanapun dan kapan saja.

Produk yang dihasilkan dari penelitian ini berupa produk media pembelajaran berbasis video materi Surat Al-Humazah yang berbentuk file mp4 dan dilengkapi dengan background musik, animasi, serta narator. Produk berupa video tersebut, menyuguhkan materi: bacaan Surat Al-Humazah, arti dari tiap ayat, asbabun nuzul, dan penjelasan serta lagu "Bibit Qurma" dari Surat Al-Humazah. File video pembelajaran yang dikembangkan sebesar $174 \mathrm{MB}$ itu sangat mudah dijalankan, meskipun menggunakan komputer dengan spesifikasi rendah, dan juga bisa diakses dikonten media youtube. Yang dilengkapi dengan backsound, teks, narator, serta animasi.

Kelayakan media pembelajaran berbasis video yang diperoleh dari validasi ahli media sebesar $96.06 \%$ termasuk pada klasifikasi sangat baik, untuk hasil validasi ahli materi sebesar $90.41 \%$ termasuk pada klasifikasi sangat baik, dan untuk respon siswa diperoleh sebesar $96.66 \%$ termasuk pada klasifikasi sangat baik. Jadi,

\footnotetext{
${ }^{30}$ Martinis Yamin, Paradigma Pendidikan Konstruktivistik (Jakarta: Gaung Persada Press, 2008). 
rata-rata total penilaian media pembelajaran berbasis video tersebut diperoleh sebesar $94.37 \%$ dengan klasifikasi sangat baik, sehingga dapat disimpulkan bahwa media pembelajaran berbasis video mata pelajaran Qurma materi Surat Al-Humazah dinyatakan layak ataupun dapat digunakan untuk proses pembelajaran.

\section{Daftar Rujukan}

Aditya, Indra. "Pemanfaatan Video Pembelajaran Sebagai Sumber Belajar Bagi Siswa Kelas 1 Program Studi Teknik Bangunan Gedung Di SMK Negeri 2 Surakarta (Pada Mata Pelajaran Praktek Batu)." Skripsi, Universitas Sebelas Maret Surakarta, 2011.

Arifin, R. "Media Pembelajaran Berbasis Video Animasi Pada Mata Kuliah Logika Dan Algoritma 1.” Bina Insani ICT Journal 4, no. 1 (2017): 83-94.

Cahyadi, Ani. "Pengembangan Media Dan Sumber Belajar Teori Dan Prosedur." Jakarta: PT. Prestasi Pusta Karya, no. January 2018 (2019): 1-9.

Fadhli, Muhibuddin. "Pengembangan Media Pembelajaran Berbasis Video Kelas Iv Sekolah Dasar." Jurnal Dimensi Pendidikan Dan Pembelajaran 3, no. 1 (2015): 24-29. https://doi.org/10.24269/dpp.v3i1.157.

Fauzan, Muhammad Aziz, and Dwi Rahdiyanta. "Pengembangan Media Pembelajaran Berbasis Video Pada Teori Pemesinan Frais." Jurnal Dinamika Vokasional Teknik Mesin 2, no. 2 (2017): 82. https://doi.org/10.21831/dinamika.v2i2.15994.

Fitria, Ayu. "Penggunaan Media Audio Visual Dalam PEMBELAJARAN ANAK USIA DINI." Jurnal Cakrawala Dini Vol. 5, no. 2 (2014): 57-62.

Hafizh, Abrar, and Ridho Bayu Yefterson. "Pengembangan Media Pembelajaran Berbasis Video Menggunakan Windows Movie Maker Dalam Pembelajaran Sejarah (Materi Pelajaran: Awal Masuk Dan Berkembang Agama Islam Di Indonesia)." Jurnal Halaqah Vol. 1, no. 3 (2019): 224-45. https://doi.org/10.5281/zenodo.3361710.

Hendriyani, Yeka, Niswardi Jalinus, Vera Irma Delianti, and Lativa Mursyida. "Analisis Kebutuhan Pengembangan Media Pembelajaran Berbasis Video Tutorial." Jurnal Teknologi Informasi Dan Pendidikan Vol. 11, no. 2 (2018).

Kamus Besar Bahasa Indonesia. Jakarta: Pusat Bahasa, Departemen Pendidikan Nasional Indonesia, 2014.

Munir. Multimedia : Konsep \& Aplikasi Dalam Pendidikan. Bandung: Alfabeta, 2012.

Munir, Muhammad. "Analisis Pengembangan Media Pembelajaran Pengolah Angka (Spreadsheet) Berbasis Video Screencast." Jurnal Pendidikan Teknologi Dan Kejuruan Volume 21, no. 4 (2013).

Mustholiq, Imam, and dkk. "Pengembangan Media Pembelajaran Interaktif Berbasis Multiedia Pada Mata Kuliah Dasar Listrik." Jurnal Pendidikan Teknologi Dan Kejuruan Vol. 16, no. 1 (2007): 1-18.

Nurdin, Arbain. "Inovasi Pembelajaran Pendidikan Agama Islam Di Era Information and Communication Technology." TADRIS: Jurnal Pendidikan Islam 11, no. 1 (2016): 49. https://doi.org/10.19105/tjpi.v11i1.971. 
Nurhidin, Edi. "Inovasi Pembelajaran Pendidikan Agama Islam (PAI) Melalui Pemanfaatan Media Pembelajaran Kontekstual Dan Pengembangan Budaya Religius Di Sekolah.” KUTTAB 1, no. 1 (March 31, 2017): 1-14. https://doi.org/10.30736/kuttab.v1i1.95.

Puspitarini, Dwi. Media Pembelajaran Pemilihan, Penggunaan, Pengembangan. Jember: STAIN PRESS, 2013.

Rasyid, Magfirah, Andi Asmawati Azis, and Andi Rahmat Saleh. "Pengembangan Media Pembelajaran Berbasis Multimedia Dalam Konsep Sistem Indera Pada Siswa Kelas XI SMA.” Jurnal Pendidikan Biologi Volume 7, no. 2 (2016): 6980 .

Sanjaya, Wina201. Media Komunikasi Pembelajaran. Jakarta: Prenadamedia Group, 2012.

Sudjana, Nana, and Ahmad Rivai. Media Pengajaran. Bandung: Sinar Baru Algensindo., 2013.

Sugiono. Metode Penelitian Kuantitatif, Kualitatif, Dan R\&D. Cetakan Ke. Bandung: Alfabeta, 2017.

Sukiman. Pengembangan Media Pembelajaran. Sleman Yogyakarta: PT Pustaka Insan Madani, Anggota IKAPI, 2012.

Sulistya, Dewi Ayu. "Pengembangan Quantum Teaching Berbasis Video Pembelajaran Camtasia Pada Materi Permukaan Bumi Dan Cuaca." Profesi Pendidikan Dasar 1, no. 2 (2018): 169. https://doi.org/10.23917/ppd.v1i2.5067.

Ulya, Himatul, Noer Hidayatul Laily, and Mukhammad Luqman Hakim. "Pengembangan Media Pembelajaran Pai Dengan Menggunakan Video Explanasi, Pop Up Dan Kahoot." Edudeena: Journal of Islamic Religious Education Vol. 4, no. 1 (2020): 39-48.

Wahyudi, Winarto Eka. "Radikalisme Dalam Bahan Ajar Dan Analisa Wacana Kritis Perspektif Van Dijk Terhadap Materi PAI Tingkat SMA." JALIE: Journal of Applied Linguistics and Islamic Education Volume 01, no. 01 (2017): 1-20.

Wardoyo, Tri Cipto Tunggul, and MT. Faqih Ma'arif. "Pengembangan Media Pembelajaran Berbasis Video Animasi Pada Mata Pelajaran Mekanika Teknik Di SMK Negeri 1 Purworejo." Jurnal Pendidikan Teknik Sipil Dan Perencanaan 3, no. 3 (2015): 1-7.

Yamin, Martinis. Paradigma Pendidikan Konstruktivistik. Jakarta: Gaung Persada Press, 2008.

Yaumi, Muhammadd. Media Dan Teknologi Pembelajaran. Jakarta: Prenadamedia Group, 2018.

Zainiyati, Husniyatus Salamah. Pengembangan Media Pembelajaran Berbasis ICT Konsep Dan Aplikasi Pada Pembelajaran PAI. Jakarta: Kencana, 2017. 